Lexis Vol. XLV (2) 2021: 825-863

\title{
Infancia y transgresión poética en la obra de Luis Hernández
}

\author{
Liz Fiorella León Mango \\ https://orcid.org/0000-0002-6179-9974 \\ Universidad Peruana de Ciencias Aplicadas \\ tchulleo@upc.edu.pe
}

\section{RESUMEN}

La infancia representó en el ideario del poeta moderno la avidez de conocimiento, el impulso lúdico-experimental y la conciencia material del arte. Estos rasgos pueden distinguirse en la obra de Luis Hernández, quien, revalorizando la infancia, planteó el ímpetu lúdico y la inocencia como claves de una producción artística original. Identificándose con la pureza de un niño, en un nivel temático, el poeta cuestionó la indolencia y el afán organizativo y alienante de todo autoritarismo. En cuanto al uso de los instrumentos técnico-formales, practicó con ellos tal y como un infante experimenta con sus objetos de juego, explotando sus posibilidades, despreocupado e irreverente. Dicho esto, nuestro objetivo es evidenciar cómo su reinterpretación de la infancia influyó en su cuestionamiento de los procesos de escritura, distribución y recepción de la literatura.

Palabras clave: Luis Hernández, poesía moderna, infancia, juego, metáfora

https://doi.org/10.18800/lexis.202102.010 
Childhood and Poetic Transgression in the Poetry of Luis Hernández

\begin{abstract}
In the ideology of the modern poet, childhood represented the lust for knowledge, the playful-experimental impulse and the material conscience of art. These features can be distinguished in the work of Luis Hernandez, who, revaluing childhood, set out the playful impulse and innocence as keys to an original artistic production. Identifying himself with the purity of a child, on a thematic level, the poet questioned the indolence and the organizational and alienating eagerness of all authoritarianism. As for the use of technical-formal instruments, he practiced with them just like a child experiments with his play objects, exploiting his possibilities, carefree and irreverent. That said, our objective is to show how his reinterpretation of childhood influenced his questioning of the processes of writing, distribution and reception of literature.
\end{abstract}

Keywords: Luis Hernández, modern poetry, childhood, play, metaphor

\title{
1. INTRODUCCIÓN
}

Luis Hernández no fue un poeta convencional. Tras haber publicado su tercer poemario, Las constelaciones (1965), optó por no editar y por dispersar su obra en un sinnúmero de cuadernos, los cuales, reunidos después por Nicolás Yerovi, serían conocidos bajo el título de Vox horrísona (1978). En este volumen, evidenció su verdadero espíritu creador dionisíaco en contraposición a la tendencia, en general, seria y comprometida con la historia que imperaba en las producciones de sus compañeros de generación (Antonio Cisneros, Rodolfo Hinostroza, Mirko Lauer, por ejemplo). Frente al panorama político-ideológico de los años 60 y 70, agitado por la Revolución cubana, el Mayo francés, el conflicto entre la Unión Soviética, EE. UU. y Cuba, el golpe de Velasco Alvarado y otros hechos, él se hallaba más acorde con la corriente de la Beat Generation y la heterodoxia pacifista y liberal que caracterizaba a los movimientos contraculturales (flower children, rockeros, 
la "onda mexicana”...), los cuales encaraban la desnaturalización y la alienación de la imaginación recusando la historia heredada, la rigidez reglamentaria y los patrones del sistema ${ }^{1}$.

En otras palabras, el poeta representó, en las letras peruanas, el ánimo disidente de los años 60-70 y desafió la racionalidad de la crítica más ortodoxa. Es más, se apartó del círculo oficial del campo literario peruano y expresó, regalando sus versos y poniendo a la deriva su escritura, su necesidad de una comunión sin límites, de alegría y amor. La amenaza de la aniquilación nuclear, después de la experiencia de la Segunda Guerra Mundial (tema que abordaría continuamente en su obra), lo conmovió y lo condujo a trascender el nivel de la ideología y a explorar sus potencias no intelectivas, para lo cual creemos que fue fundamental su reinterpretación de la infancia. Por lo expuesto, proponemos indagar cómo, asumiendo la libertad y potencia creativa de un niño, nos legó una obra inaudita con la que evidenció su fervor por la creación y el arte de la poesía como un juego y una concepción transgresora que lo situaría, en un principio, en la heterodoxia del campo literario peruano.

\section{Luis Hernández ANTE la CRítica: UN Hito EN EL PROCESO DE TRANSGRESIONES POÉTICAS}

Crear una obra estructurada presta para la industria editorial no era una de las mayores ambiciones de Luis Hernández después de que presentara Las constelaciones en el concurso Poeta Joven del Perú y se "negara" a formar parte de la antología Los nuevos (O’Hara 1995a: 25), libro que oficializó el nacimiento de la llamada "Generación del 60". Más bien, optó por dispersar y obsequiar cuadernos inéditos con su poesía hológrafa, la cual recién empezó

\footnotetext{
1 Luis Hernández apreciaba la belleza hasta de los objetos más “insignificantes” de la vida. Las esquinas de las calles, los parques, los bares y el mar eran sus insumos cromáticos. No comprendía la violencia, procuraba la armonía y se rehusaba a transformar la poesía en un campo de militancias. En este sentido, el perfil del “poeta guerrillero”, que encarnaba su coetáneo Javier Heraud, le generaba suspicacias. Estaba convencido de que la verdadera revolución solo era posible con la cultura y la música (Romero 2008: 32).
} 
a ser reconocida oficialmente desde que Alberto Escobar (1973), en su Antología de la poesía peruana, declarara al autor como un poeta clave en las nuevas líneas de creación de los años 60, abiertas a la tradición inglesa y a la innovación de los parámetros poéticos ${ }^{2}$ (31).

A partir de entonces, los críticos, con la pretensión de legitimar la poética de Luis Hernández, comenzaron a visualizarlo desde un enfoque histórico-literario. Así, por ejemplo, González Vigil (1978) lo comprendió en dos periodos de producción: en el lapso 1955-1964, al lado de César Calvo, Gonzalo Rose, Javier Heraud y Washington Delgado, por su lirismo depurado, lenguaje sencillo, tono cadencioso, paisaje apenas urbano y textura de "arte menor”; y en el lapso 1964-1966, junto a Rodolfo Hinostroza, Marco Martos, Antonio Cisneros y Julio Ortega, por su apertura a la tradición literaria inglesa, su coloquialismo, prosaísmo, parodia, ironía, urbanidad y erudición cultista (distinto de sus coetáneos por su espontaneidad, exento de tecnicismo o intelectualismo) (20). Entre ambos periodos de creación, cobraría mayor notoriedad el segundo (López y O'Hara, 1998) ${ }^{3}$, ya que representaba el cuestionamiento y la renovación del lenguaje poético en la tradición

\footnotetext{
2 Antes de este reconocimiento, Luis Hernández no figuraba en las antologías de la época ni en los comentarios críticos a la nueva generación. Véase, por ejemplo, además del clásico de Cevallos (1967), Carrillo (1965), Escobar (1965), Orrillo (1968), Tola de Habich (1969), Tamayo (1970), Ortega (1971) y Rowe (1974). Un caso aislado en este contexto de recepción fue la antología Poesía (1963), de Sologuren, quien estaba familiarizado con su estilo por haber editado Orilla (1961) y Charlie Melnick (1962). Pocos fueron los que le prestaron una atención que podríamos considerar "oficial”, y ello solo ocurrió a partir de la publicación de Escobar (1973). Luego, aparecerían los textos de Verástegui (1975), Yerovi (1976) y una serie de homenajes publicados en La Prensa, El Comercio, La Crónica, Kilka, Macho Cabrío, La Vaca Sagrada, etc., tras el deceso del escritor.

3 López y O’Hara (1998) reafirmaron la pertenencia de Hernández al segundo grupo planteado por González Vigil. Según esta tendencia crítica oficial, el poeta trabajó a su modo el estilo narrativo, la transgresión de una lírica inmaculada y el abordaje de lo cotidiano, experimentaciones con las que se condujo, con base en una renovación del lenguaje poético, a una práctica de desacralización de la poesía misma (Cfr. Higgins 1993: 151-155). Al respecto, de acuerdo con Zapata y Mazzotti (1995), si atendemos este interés por la experimentación léxica, pueden hallarse sus antecedentes en González Prada, poeta que incorporó palabras quechuas en sus Baladas pernanas; César Vallejo, quien incluyó la palabra oral de los Andes en el lenguaje poético de Los heraldos negros;
} 
literaria peruana. Así, se afirma que, a partir de la experiencia lingüística de Hernández, junto con la de Manuel Morales, se creó la antesala del coloquialismo de los años setenta (piénsese en Hora Zero) y ochenta (con Kloaka), en la cual se incluirían las voces de los marginales en el discurso literario para potenciar su desacralización (Zapata y Mazzotti 1995: 24).

Debido a esta orientación innovadora, desde una perspectiva histórica más amplia y aguda, en la actualidad, se contempla el quehacer poético de Hernández en la línea de la poesía moderna peruana fundada por José M. Eguren, César Vallejo, Martín Adán, Oquendo de Amat, Jorge Eielson y Emilio Westphalen (O’Hara 1995b: 55; Ortega 1988: 32). En este sentido, García-Bedoya (2012: 250) considera a Hernández un escritor "neovanguardista", ya que con su poesía y la de sus coetáneos renació la tendencia experimental y renovadora de los años veinte, después del periodo de moderación que representaron los años cuarenta y cincuenta.

No obstante, Hernández no solo fue uno de los que propiciaron la renovación del lenguaje poético. Su ánimo transgresor alcanzó incluso las bases de la historia literaria, incitando a repensar cómo se construye la tradición poética del Perú, sus categorías y los discursos en torno de ella. Debido a esto, se ha estudiado dicho ímpetu en diferentes objetos: Yerovi (1976), por ejemplo, a partir de la edición de Vox horrísona, señaló que su "poética [era] desmitificadora” del quehacer literario y el prestigio del poeta tradicional, ya que estaba basada en la legitimación de la imperfección y la espontaneidad ingeniosa como medios de creación (XLVII-L) ${ }^{4}$. Asimismo, Chueca (2006) resaltó su desmitificación del concepto ideal de nación (central en la construcción del canon decimonónico), lo cual efectuó a partir

y Carlos Belli y Pablo Guevara, que tentaron la coexistencia del verbo del Siglo de Oro junto con la replana urbana.

4 Precisamente por esta forma desenvuelta de escribir, González Vigil (1978) negó a Hernández su homologación poética con Martín Adán, cuya obra consideraba más sólida. Por el contrario, en los últimos años, O’Hara (2007) ha refutado esta "cantaleta del poeta facilongo, irrelevante" (29-30) y señala que su escritura corresponde a una poética entre la broma y la motivación metafísica (37), gracias a la que se cuestionan los parámetros ideológicos de su contexto y se establece una familiaridad con la cultura. 
de la revelación de su inorganicidad y la crítica de la visión turística o idealizada sobre la capital (70-87). También, Mendoza-Canales (2009) ratificó el ímpetu transgresor de Hernández al evidenciar cómo, mediante su iconoclasia y uso de la parodia, desestabilizó la autoridad de la tradición literaria como un espacio simbólico de consagración, pues la reveló cual construcción cultural basada en los intereses de un sector que monopoliza el gusto y la noción que se tiene sobre lo “artístico” (263). En sintonía con esto, Chueca (2010) ha destacado la transgresión que realizó Hernández sobre los géneros con los que se "organiza” nuestra historia literaria: la narrativa fragmentaria de los cuadernos que constituyen Una impecable soledad, planteada como una parodia de la novela de folletín en tensión con el poema en prosa (281), en la que se manifiesta el juego del poeta con las categorías históricas de la literatura. Por último, Rodríguez (2011) ha añadido otro blanco de transgresiones: el concepto estético de la "originalidad", legitimado en la historia literaria desde el Romanticismo. En su opinión, al usar lúdicamente el plagio como recurso intertextual, el poeta creó una pluralidad discursiva con la que cuestionó la homofonía de la poesía y el aura mítica del creador como único pilar de su producción $(120)^{5}$.

Concordamos con los puntos señalados como blancos de las transgresiones del poeta. No obstante, nos preguntamos ¿cuál es el eje de esa pulsión transgresora? La despreocupación del poeta por los valores tradicionales, su constante búsqueda de asombro y su continua mención de la inocencia como condición para la plena

\footnotetext{
5 Ciertamente, en la obra de Hernández, aflora una multiplicidad de voces con las que el yo lírico dialoga o que traduce, resemantiza y repite en diferentes cuadernos. Se trata de una práctica de reescritura dialógica y polifónica continua, a la que Mendoza-Canales (2013) ha denominado una "poética del devenir" ("un flujo voluntariamente desordenado”, en palabras de O’Hara [1997: XXIII]), en la que se sustenta la inorganicidad de su obra. Al crear una obra acéntrica que tiende a la dispersión y el cambio continuo, con el único fin de "poetizar sobre el poetizar mismo" (206) (poïein), evidencia la imposibilidad de lograr el conocimiento de lo Absoluto tanto como su necesidad de trascendencia. Al respecto, Vich (2013) arguye que el reconocimiento de esta crisis en Hernández podría esclarecer su comprensión de cómo el lenguaje es una herramienta imposibilitada de simbolizar lo real o comunicarlo y que solo se puede tantear figuraciones con él en la práctica artística (29-31).
} 
expresión artística nos conducen a pensar que se basó en la reivindicación estética de la infancia, una de las fuentes más significativas de la poesía moderna de cuño vanguardista. Su autopercepción como un niño curioso (llamándose "Lucho" o "Luchito" en sus cuadernos hológrafos) se avizoraba desde las entrevistas que le hiciera Alex Zisman (1975a, 1975b), en las cuales evidenció su ánimo juguetón y sencillo, su captación cromática de la naturaleza, su espontaneidad creativa, su placer en el ejercicio caligráfico-lúdico-poético y su desinterés por los enseñoreados críticos literarios. De este modo, la tendencia a desmitificar al "poeta” y el ejercicio creativo señalado por Yerovi (1976) podría entenderse a la luz de esta figura: el niño que ignora en su primera infancia las jerarquías y los parámetros del arte, actuando como un demiurgo que recrea o destruye su entorno organizado y solemnizado. Así, también, ignora su patria y su idioma, que representan límites incomprensibles, más aún si se imponen como herencia irreprochable. Por ello, cuando Chueca (2006) indica que el poeta se burla de la visión sublimada del concepto de nación, se puede añadir que esta actitud se nutre del impudor infantil del poeta, quien no tema señalar las grietas de lo dado culturalmente. La autoridad de la patria, la tradición literaria señalada por MendozaCanales (2009), y el encarecimiento de la cultura literaria y del lenguaje poético apuntados por Chueca (2010), Rodríguez (2011), Zapata y Mazzotti (1995), y López y O’Hara (1998), son vaciados de su sentido ante los ojos transgresores de la infancia, la cual es reivindicada por el poeta como parte de su cosmovisión por la libertad que le brinda para jugar artísticamente y recrear el mundo circundante.

Bajo este lente, la poesía de Hernández podría ser comprendida en su real dimensión si la estudiásemos en la línea de creación de los vanguardistas peruanos, tal y como lo proponían Ortega (1988), O’Hara (1995b) y García-Bedoya (2012), pues, en efecto, la esencia disruptiva de su poesía expuesta como objeto atípico que reafirmó la autonomía de la práctica artístico-literaria ante la tradición poética canónica es un eco del arte moderno. Es necesario profundizar en esta idea que apenas ha sido señalada. Por ende, planteamos como fundamento teórico una revisión de la categoría del "artista 
moderno-niño", con el fin de esclarecer la raíz estética de esta interpretación. Realizado ello, será posible mostrar cómo la poesía de Luis Hernández puede entenderse, en palabras de Paz ([1974] 1993), dentro de esa "tradición de la ruptura”, por problematizar los procesos de creación, distribución y consumo de la literatura.

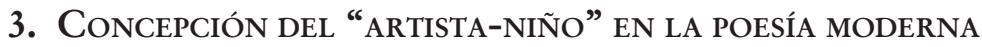

El concepto del niño como metáfora del artista fue constituyéndose con claridad a fines del siglo XVIII'. Una fuente importante para ello fueron las Cartas para una educación estética del hombre, de Schiller ([1795] 2016), quien ejecutó, en consonancia con algunos principios kantianos, una interpretación estético-política del niño. Él aseveraba que el hombre "moderno" estaba adormecido por una vida mecánica y que la única forma de que se reconozca como “persona” era recuperando conscientemente su niñez (un "nuevo estado de naturaleza”), para poder reencontrarse con su autonomía y ennoblecer su espíritu a través del arte y el juego. Solo de esa manera, según lo planteaba, era posible un mejoramiento de la esfera política, en la cual el artista-niño cumpliría un rol fundamental. Según Guerrero (2008), los escritores de tendencia romántica (piénsese en Blake, Wordsworth, Jean-Paul, Coleridge, Novalis...) asimilaron esta valoración moderna de la niñez y, por ello, exaltaron la magia, la imaginación, el sueño y el inconsciente,

\footnotetext{
6 Antiguamente, la niñez no era apreciada como en el siglo XXI. Desde la perspectiva medieval, por ejemplo, el infante era visualizado como un homúnculo, un ser básicamente frágil, inferior e imperfecto que debía ser disciplinado hasta convertirlo en un adulto-superior. Este punto de vista iría cambiando entre los siglos XVI y XVIII, periodo en que se exploró su verdadero potencial. En este intervalo, fueron fundamentales las reflexiones de dos pensadores: Erasmo de Rotterdam, quien en su texto De Pueris (1530) reivindicó al niño y su natural curiosidad intelectual, así como reconoció que una herramienta sustancial para su formación liberal era el juego; y Rousseau, filósofo que, en Émile, ou De léducation (1762), señaló la necesidad de proteger al niño de la comprensión progresiva de la historia y del individualismo utilitario. Según este pensador, el niño no podía ser tratado como un ser minúsculo al que había que entrenar y evolucionar en internados; por el contrario, creía en la necesidad de permitir su libre desarrollo en un estado natural y de feliz inocencia, en oposición al progresismo y la decadencia de las instituciones que esclavizan al hombre tanto como debilitan su condición humana.
} 
considerándolos piezas fundamentales para repoetizar el mundo trastocado por la civilización ${ }^{7}$.

Esta comprensión estética de la infancia cobraría forma con las observaciones de Baudelaire (2005) en su escrito "L'Artiste, homme du monde, homme des foules et enfant", donde planteó el concepto del "artista-niño" en oposición a la razón instrumentalizada y progresista, puesto que consideraba que su temperamento inquieto era una cualidad contraria al espíritu embotado y el hastío reinante del mundo burgués. Para explicar esta categoría, se basó en la descripción de Monsieur Constantin Guys, caracterizado con una naturaleza infantil, no en un sentido peyorativo, sino, por el contrario, como expresión de un empoderamiento. Resaltó en él el quid de su potencia: la curiosidad, irrefrenable y alegre, y determinó esta facultad como clave para convertirse en un bizarro "pintor de la circunstancia y de todo lo que ella sugiere de eterno" (22), pues permite contemplar y acumular todo del mismo modo como un niño lo hace: con avidez, asombro, excitación y democracia. No obstante, puntualizó que este "genio" que reivindica voluntariamente su infancia como foco de su imaginación creadora equilibra su potencia con una inteligencia analítica, lo cual le permite convertir su experiencia en expresión poética.

En el siglo XX, se afianzaría dicha interpretación del artista moderno como un niño y se resaltaría, incluso, su cualidad irracional, gracias a las corrientes vanguardistas principalmente. En la línea de la "modernidad estética", entendida como una reacción contra la "modernidad histórica" (Calinescu 2003), críticos de las degeneradas promesas de la civilización, los vanguardistas buscarían en el arte primitivo, la infancia y lo salvaje unas fuentes de inspiración para revolucionar la poesía, entendida como un medio para instaurar "otro tiempo" (Paz [1974] 1993: 69) o, en palabras de Habermas (2004), una nueva conciencia del tiempo. No se trató de

\footnotetext{
Esta vuelta deliberada al principio (la edad de oro, cuyo tiempo no se haya sometido al reloj) era un paso para romper el espejismo progresista de la modernidad, pues implicaba una revolución en la conciencia del tiempo (Paz [1974] 1993: 60). Se observaría, por ejemplo, en el comportamiento disidente del enfant terrible Arthur Rimbaud, que voceó el imperativo de volverse un salvaje, vigoroso, espontáneo y sincero.
} 
una superflua evasión o una gratuita aceptación de la marginalidad. Para ellos, hacerse salvajes y plasmarlo en la obra de arte era una oportunidad para fracturar la continuidad de la historia y generar nuevos hallazgos. Esto lo ejecutaron, por ejemplo, al emplear elementos estéticos del pasado de forma provocativa. Con ello, se opusieron simultáneamente a una falsa normatividad de la historia.

Bajo este lente, los fauvistas, cubistas y surrealistas, fascinados por el arte originario de Europa y África, las manifestaciones artísticas populares americanas y orientales, y las expresiones espontáneas del arte infantil, asimilaron sus procedimientos como parte de su experimentación formal. Activamente, entonces, promovieron una liberación de los parámetros de creación tradicionales y una renovada sensibilidad vital ${ }^{8}$, enérgica, saludable, humana, natural. En consecuencia, concretaron obras sinceras y originales. Por ejemplo, el cubista Picasso, ejecutando su intención de "aprender a dibujar como un niño”, logró alejarse del arte imitativo y generó una nueva percepción formal de la realidad; el expresionista Oskar Kokoschka, rehusándose a enmendar sus lienzos, alcanzó la ansiada autenticidad que buscaba; y Georg Grosz exteriorizó vívidos sentimientos practicando un trazo rústico similar al de los infantes (De Micheli 2000: 109). No obstante, sin duda, fueron los dadaístas quienes agudizaron esta agitación formal como parte de la reivindicación de la infancia. El caso que mejor ilustra esta actitud es el de Tristan Tzara (2009), esquivo ante el imperativo de la ejecución de una "obra” trascendente y promotor del cuestionamiento del concepto “arte”, ya que este, bajo sus términos, no podía ser un asunto serio, igual que todos los otros principios impuestos a lo largo del tiempo (190). En cambio, practicaba la contemplación del mundo con la transparencia de la percepción infantil, para aprehenderlo en su simplicidad. En virtud de esto, como parte de esta nueva mirada, de acuerdo con Barroso

\footnotetext{
8 Algunos declaraban que eran los primitivos de una renovada sensibilidad (futuristas) o se catalogaban como bárbaros y locos en rechazo a la civilización corrompida (surrealistas, dadaístas) (De Torre, 2001: 187, 386). Paul Klee, según Sologuren (2005), expresaba particularmente su deseo estético de ser como un niño, inconsciente de la moral, las modas, la historia y las técnicas, para poder generar un motivo artístico personal.
} 
(2005), otro dadaísta como Hugo Ball comprendía la infancia como una instancia de autonomía ignorada o subestimada que debía ser ponderada si se deseaba aprehender la esencia filosófica del arte (267).

Después, dicha tendencia transgresora inspirada en la infancia se vería, de cierto modo, en las obras de Wifredo Lam (autor de La jungla), Jackson Pollock (iniciador del action painting), Jean Dubuffet (fundador del “Art Brut”) y las corrientes artísticas llamadas “neovanguadistas” surgidas luego de la Segunda Guerra Mundial. Así mismo, influenciaría en la "contracultura" de los años 60, irresponsable, alegre, popular, antiautoritaria, comunal: en el "iracundismo" inglés (incrédulo y disconforme con el stablishment) y el "frenetismo" norteamericano ("hípsters”, “coolcats”, "beatniks”, "holy barbarians", alineados en reacción frente a la deshumanización instaurada desde el corazón de las instituciones [De Torre 2001: 805-806]). En este nuevo contexto, bajo nuestro lente, el artista-niño intentaría nuevos modos de superar cualquier intento de estandarización.

Dado lo expuesto, hemos querido evidenciar que nuestra comprensión del artista moderno como un niño no es gratuita, puesto que tiene antecedentes desde las reflexiones filosóficas y estéticas del siglo XVIII. Nos interesa, particularmente, la idea de que un artista, con una clara intención crítica, reivindique su infancia como fuente inspiradora de creatividad, libertad y transgresión. Consideramos, pues, que la infancia es como un nervio indesligable de la existencia del hombre, no una etapa superable ni un estadio prelingüístico que "evoluciona" desde un reconocimiento del lenguaje. De acuerdo con Agamben (2007), la infancia y el lenguaje no se pueden ordenar sobre un tablero cronológico, pues se remiten mutuamente desde el momento en que el sujeto se inserta en la historia y, del mismo modo, continúan articulados en cada experiencia hasta la muerte (66). No se trata de una edad de oro superada, sino olvidada, relegada en toda su potencia. El poeta moderno la redescubrió y, a partir de ella, asumió plantearse una nueva relación con el lenguaje: su experimentación poética se convirtió así en el núcleo de un nuevo modo de hacer historia, para arribar a una nueva consciencia recreativa del mundo. 
En este sentido, debido a la importancia del tema de la infancia que reconocemos en la producción artística de Hernández, estudiaremos dos formas de su manifestación que se hallan en tensión. Por un lado, evidenciaremos la representación del niño en algunos de sus escritos, los cuales, de cierto modo, poseen un trasfondo religioso, o, más específicamente, la influencia del espiritualismo romántico. Esto se percibirá en la configuración mística del artistaniño-ángel, quien demuestra una facultad divina, visionaria, pero incomprendida y solitaria. Por otro lado, expondremos cómo de dicha representación del artista-niño perseguido y marginal se pasa a su empoderamiento en la configuración formal del yo poético moderno, revelado como un artista-niño curioso y transgresor en su experimentación técnico-literaria. Creemos que Luis Hernández, tras una reivindicación de su soledad de niño con potencia creadora, planteó la necesidad de una resistencia ante la estandarización, y una repoetización del mundo por medio del juego, la música y su inocencia, una que, en su poesía, deja de ser expresión de fragilidad para trastocarse en fuerza creadora ${ }^{9}$. Así, usando recursos infantilvanguardistas, el poeta pudo cuestionar los parámetros formales reconocidos en el campo literario de los años sesenta.

Con el fin de concretar esta interpretación, metodológicamente, emplearemos, en primer lugar, conceptos de la Pragmática Lingüística. Por ello, es importante mencionar a los interlocutores, quienes pueden ser locutores ("locutor personaje" - yo poético que expresa una emoción de forma individual o colectiva- o "locutor no personaje" — que se manifiesta de modo impersonal-)

\footnotetext{
9 La inocencia, desde una perspectiva romántico-cristiana con un trasfondo rousseauniano, alude a una sensibilidad incontaminada que faculta al niño para existir en armonía con el mundo y la naturaleza. No obstante, desde el punto de vista moderno de Nietzsche, y que influiría en parte de la obra de Luis Hernández, la inocencia entendida así revela fragilidad o vulnerabilidad, pues evidencia la incapacidad para cuestionar lo dado culturalmente; de este modo, una sentencia judeocristiana animaba a los discípulos a poseer el corazón de un niño para poder entrar en el reino de los cielos. Nietzsche, por ello, distingue la inocencia de otra forma, por su empoderamiento, uno que posibilita el libre cuestionamiento y la creación de nuevos valores. En próximos acápites se observará cómo ambas condiciones de la inocencia, la de la vulnerabilidad y el empoderamiento, confluyen en tensión en la poesía de Hernández, cualidad típica de su producción atravesada por dicotomías.
} 
y alocutarios ("alocutario figural" -instancia receptora, concretamente expresada en segunda persona-, "alocutario no figurado" -intangible, aunque presupuesto en el cuerpo poético- - "alocutario cero" (típico en aquellos textos poéticos en los que el locutor personaje se exhorta a sí) (Fernández [2001] 2009: 174-181). En segundo lugar, para comprender la visión de mundo en la poesía de Hernández, analizaremos sus procedimientos figurativos apoyados en la teoría cognitiva de Lakoff y Johnson (1995), dos investigadores que prestaron una gran atención a la metáfora no como un simple "desvío" en el lenguaje, sino como un factor fundamental del engranaje conceptual del hombre en su vida cotidiana. Destaca entre las afirmaciones de estos estudiosos, la naturaleza compartida de la metáfora en una sociedad o un "campo retórico"10, cuyo reconocimiento posibilita que se efectúe la comunicación y la acción. Se trata de una figura que, pese a que no lo notemos, organiza nuestras percepciones, pensamientos y acciones en términos de estructuras, orientaciones y conceptos. Por ejemplo, cuando decimos "salir herido de una discusión”, estamos ante una metáfora que estructura un concepto con el contenido semántico de otro (un debate es una guerra); si afirmamos “caer en depresión” o “crecer como personas”, nos encontramos ante metáforas orientacionales que organizan nuestra percepción y nuestra experiencia física y cultural en términos espaciales, pues vinculan tristeza/abajo, bueno/ arriba; por último, cuando manifestamos "estar muy oxidados para bailar”, evidenciamos la concepción ontológica de nuestra experiencia en el mundo bajo el sentido de objetos y sustancias. Pero precisemos lo siguiente: comprendemos el significado de esas expresiones porque poseemos un bagaje lingüístico-cultural común,

\footnotetext{
10 Adoptamos esta categoría de Arduini (2000), entendiéndola como el área conceptual que funciona como soporte de los "medios antropológicos-expresivos", el cual posibilita la interacción y comprensión, en este caso, en el ámbito artístico-literario occidental (62). Además del "campo figurativo" de la metáfora, Arduini considera la existencia de otros cinco, con los cuales se organiza la expresión humana dentro de “campo retórico": metonimia, sinécdoque, elipsis, antítesis y repetición. En la poesía de Hernández, predominan los dos últimos campos mencionados junto con la metáfora, lo cual se irá evidenciando en el análisis de su obra.
} 
en el cual la metáfora halla su lugar. Dicho esto, cuando estudiemos la metáfora hernandiana el artista es un niño, no debemos perder de vista su concepción dentro del “campo retórico" de la poesía moderna (desde el romanticismo hasta las vanguardias), ya que, en él, cobran sentido sus versos y experimentaciones.

\section{Representación del artista-Ángel-niÑo en el $A R S$ POÉTICA DE LUIS HERNÁNDEZ}

Gilman (2003) afirma que la confrontación político-militar de las dos mayores potencias mundiales de los años sesenta (Estados Unidos y la Unión Soviética) produjeron una gran incertidumbre y rechazo entre las nuevas generaciones (36). Tras el trauma ocasionado por los bombardeos nucleares de la Segunda Guerra Mundial (escenario que evidenció cómo el racionalismo instrumental se degeneró en "irracionalismo", en palabras de Adorno [1998]), la nueva crisis formó en el imaginario colectivo la amenaza de un desenlace fatal para la humanidad. Frente a este escenario empobrecido, Luis Hernández, influenciado por los movimientos contraculturales y su crítica de la prepotencia de las autoridades, empleó la metáfora del artista-niño para reivindicar la libertad, especialmente la libertad creadora ensombrecida en su contexto, y así presentarla como fuente de nuevas experiencias.

Es particularmente interesante cómo el poeta comprende al músico prodigio, el poeta disidente y el ángel al mismo nivel que un niño. Son, para él, seres excepcionales que incluso podrían ser considerados guías de la humanidad. No obstante, Hernández los representa cual víctimas de la indolencia o el despotismo de las instituciones. Su diferencia o genialidad atemoriza y, por ello, se tienta a administrarlos, cosificarlos, instruirlos o, incluso, torturarlos. Veamos, por ejemplo, cómo se establecen estas relaciones en el texto "Los ojos del niño Mozart” (293), de Ars poética"

\footnotetext{
11 En adelante, todas las referencias textuales a la poesía de Luis Hernández se realizarán con respecto a la edición de Mora de 1983, por ser una versión ampliada de la que realizó Yerovi con la contribución del propio autor mientras vivía. Consideramos que
} 
Muero por delicadeza

J. A. Rimbaud

\author{
LOS OJOS del niño Mozart \\ Son los ojos \\ De todos los niños del mundo \\ Los ojos del torturado cuerpo \\ Del poeta Arturo Rimbaud \\ Son los ojos de los niños \\ Las categorías de Ángeles son: Ángeles \\ Arcángeles Tronos \\ Potestades Dominaciones \\ Querubines y Serafines
}

En el plano de la dicción textual, resalta la concurrencia de los términos artísticos (Mozart y Rimbaud) con los religiosos (serafines, tronos, ángeles, querubines, etc.), la cual visibiliza el estrecho vínculo entre el arte y la religión. Se trata de una relación de larga data que nos recuerda una tensión: el artista (personificado por el niño Mozart), antiguamente, estaba sometido a los designios del orden moral y religioso, por lo que dependía de la Iglesia tanto como de un patrón cortesano. Sin embargo, el dúo "arte-religión" también está marcado por una relación armoniosa, de raigambre romántica. Esta se evidencia en la mutua consideración de la pureza como una cualidad propia de una condición espiritual superior. El artista-niño (personificado por Rimbaud), si bien no es útil para la burguesía potentada, puede guiarnos ante el misterio y lo inefable gracias a su condición de "iluminado". Su capacidad visionaria, por ello, es evidenciada en el nivel retórico, por medio de la repetición

todo "orden" adicional que se le dé a su obra en ediciones posteriores (tipo antología, por ejemplo) mella en el significado y propósito de su devenir y transgresión creativa. Una intención similar de conservar la organización propuesta por los primeros editores de Vox horrísona fue también la que guio a O’Hara (1997: xvi-xvii) en la publicación del libro Una impecable soledad, puesto que, como bien afirma, el carácter juguetón de Hernández impide que se pueda encorsetar su obra bajo los parámetros de un riguroso trabajo editorial basado en fechas. 
y la metáfora: respectivamente, la anáfora de "los ojos” demanda nuestra atención sobre la cualidad de observadores (videntes) de los personajes representados; y la metáfora ontológica los artistas son niños (establecida sobre la equivalencia entre los “ojos” de Mozart y Rimbaud con los de todos los niños del mundo) plantea su condición de pureza común.

En la base de esa metáfora se halla lo que Octavio Paz ([1974] 1993) denominó “una doble tentación”: una revolucionaria y una religiosa. Por una parte, en la línea de los vanguardistas de mediados del siglo XX, la revalorización de la infancia significó para Hernández una reinterpretación de la inocencia, la transparencia y la sinceridad como medios de resistencia ante un contexto abatido en el que urgía "nacer nuevamente" u "observar con ojos nuevos", para construir desde las ruinas una nueva praxis vital, una en la que fuera posible, bajo un punto de vista artístico, una renovada comunión con el entorno cotidiano (los amigos, el océano, las flores, los jardines...). En realidad, este era un síntoma de que el poeta había perdido su fe en los grandes relatos. Por otra parte, se evidencia un trasfondo religioso. Esto se explica por la influencia del espiritualismo romántico en su poesía y por el claro interés del poeta en la herencia cultural semítica, que aparece en el subtexto de muchos de sus poemas, por ejemplo, en las referencias a la metáfora de la Caída o la separación de la armonía idílica, las cuales son acompañadas por manifestaciones de dolor. Este es el caso, por ejemplo, de la representación del "torturado cuerpo / del poeta Arturo Rimbaud". El uso de la aliteración en esos versos, en los que se reiteran los sonidos de las consonantes “ $\mathrm{t}$ ” $\mathrm{y}$ “ $\mathrm{r}$ ”, ocasionan un impacto semántico, ya que es un ruido fonético que revela una desarmonía, como si se tratase de comunicar el tortuoso camino que siguen los “iluminados” (ángeles caídos) antes de su reconocimiento como tales. Mientras tanto, son administrados ("torturados"), como se evidencia en el nivel de la dispositio del texto, que presenta a los ángeles organizados gráficamente en dos columnas cual si fueran pabellones.

Dicho esto, es importante el paratexto que apertura el poema: "Muero por delicadeza", el cual es un verso traducido de la 
"Chanson de la plus haute tour" de Rimbaud (2005 [1873], con quien Hernández se hallaba bastante identificado. En ese texto, se expone la condición de pureza de la juventud "esclavizada", que solo puede ser liberada por obra del amor y la soledad, ya que, de otra forma (oponiéndose directamente a la autoridad, por ejemplo), peligraría de ser atormentada. Esta condición de vulnerabilidad del joven se repite también en otro poema del poeta francés, "L'ange et l'enfant", en el que los niños son representados como entidades superiores a la hipocresía y la traición. Su "caída" en la tierra, marcada por el dolor del nacimiento, solo puede ser superada por medio del retiro o la muerte. De este modo, el retorno al origen (el cielo, al lado de los ángeles) es necesario para recuperar la pureza perdida, el estado de iluminación. Claramente, Hernández se nutrió de estas ideas rimbaudianas; por ello, lo citó constantemente y repitió la relación niño-artista-joven-ángel en sus poemas, para evidenciar su condición de excepcionalidad incomprendida y en peligro. Recuérdese, verbigracia, "A jean-Arthur Rimbaud" (Ofrenda lírica), donde lo interpela como a un alocutario figural claro del siguiente modo: "Triste también / hermano mío / a ti te / enloquecieron / (...) Y tú llevabas / en ti aquello / por lo cual gira / sobre su axis La Tierra / Pero excavaron / tu cuerpo y tu alma / Y pretendieron doblegar lo indoblegable / Triste hermano / Las jerarquías / De los Ángeles / son muchas” (447-448).

La representación del artista como depositario de un resto divino es sugerente a nivel temático por su carácter romántico. Evidencia la capacidad visionaria de los personajes representados: el músico, el poeta, el ángel y el niño comparten la condición de iluminados, motivo por el que pueden contemplar el universo en su esencia, amplitud y complejidad mejor que el común observador ${ }^{12}$. Por ello,

\footnotetext{
12 La representación del artista como un “iluminado” es constante en Hernández. Un texto que lo ilustra es "Soy Luchito Hernández" (de El sol lila), donde el "yo poético" se define a partir del reconocimiento de su diferencia y su autopercepción como un ser de "luz". Por ello, evidencia problemas de comunicación con el otro (es "silencioso") y la asunción necesaria de su retiro (es "solitario”): "Soy Luchito Hernández / Ex campeón de peso welter / Poca gente me habla / Hasta oí a alguien / Preguntarme / ¿De qué te defiendes? / Y yo hubiera respondido / Si no silencioso fuera: / Más bien te defiendo
} 
la constante mención del sentido de la vista revela una fascinación por ella y, al mismo tiempo, una preocupación por su degeneración a causa de las imposiciones de las instituciones (Mozart, de la Corte ${ }^{13}$; Rimbaud, de la familia; los ángeles, de la Iglesia Católica; los niños, de los internados). Al mismo tiempo, nos enrostra el estado de marginalidad del poeta moderno. Sin embargo, a pesar de ello, al igual que un niño que no mide el peligro de sus profanaciones, Hernández, en otros textos, refutará la regulación y negará con sus experimentaciones formales (sinceridad, improvisación, humor blanco y juego) ser un siervo de la naturaleza o del sistema. Ilustrativamente, comunicará las imágenes en su estado puro, como consecuencia de su visión de lo “maravilloso cotidiano” de la vida. En razón de esto, es relevante en la poesía de Luis Hernández la repetición constante del verso “A través de tus ojos, tu corazón” (que en ocasiones aparece traducido al inglés como "Through your eyes / to your heart”), pues invita al lector a asumir al igual que él la sinceridad como un modo de recomponer la condición humana corrompida desde el arte.

\section{REPRESENTACIÓN DEL NIÑO SOLITARIO EN “CHOPIN": EMPODERAMIENTO Y REVOLUCIÓN}

La soledad, en la poesía de Luis Hernández, aunque en ciertos momentos se representa como una condición difícil de sobrellevar,

\footnotetext{
/ De mi luz. Una luz / Que reuní y me friega” (196-197). Su inclinación por su autorreconocimiento como un niño ("Luchito") implicó una reivindicación de su pureza, “conquistando su propio corazón”. De este modo, podía observar la muerte sin temor, igual que Rimbaud, que expresaba el retorno del niño al cielo no como una desgracia, sino como una oportunidad. Tal vez, por este motivo, expresaba en otro texto: "Pero algo / hay de mí / que me asola / no obstante / yo veré a Dios / y mis ojos / han de contemplarle / a quien veré por mis ojos propios / Y no como un extraño" (234-235).

13 Léase a Baldoni (2012), quien comenta la tragedia del genio solitario Mozart. Para ser un "artista libre", este tuvo que encarar el gusto de la Corte, lo cual le generó un obstáculo en el desarrollo de su proyecto vital y la indolencia del público vienés, pues este no comprendía el viraje inusual en su música. La misma incomprensión sufrió Arthur Rimbaud, quien como sujeto atípico solo pudo sobrevivir en el espacio poético que creó de manera personal, ya que como hombre de carne y hueso los apuros materiales lo enajenaron ("torturaron”).
} 
es reconocida generalmente como un estado idóneo para la creación. Así, por ejemplo, en Elegías, el poeta cita a Percy B. Shelley: "the strenght of gladness come to my spirit in my solitude" ("la fuerza de la alegría viene a mi espíritu en mi soledad”) (256). Apartado de las fuerzas influyentes del sistema, el artista-niño puede crear un tiempo alternativo, el del juego y la liberación de la imaginación, una oportunidad para liberarse de las jerarquías, descubrir y lograr nuevos conocimientos (v. Huizinga 2007). En este sentido, el llamado al espléndido retiro que realizaba Rimbaud se celebra, por ejemplo, en "Chopin” de El curvado universo (87), donde se trastoca la vulnerabilidad del artista-niño en empoderamiento, una ocasión para la liberación de la canción más íntima.

\section{CHOPIN}

Se sintió primero

Con la tristeza

De un niño solitario

Y luego

Con la grandeza

De un niño solitario

Y escribió

Aquella Música

De su alma

Que es lo único

Que pudo

Bajo un sol

Que no era el suyo

Dar su Amor

AH TRISTE tañedor

Del laúd:

Ese era tu secreto

Y lo he olvidado 
En los versos citados observamos, una vez más, el estrecho vínculo establecido entre el músico, el niño y el poeta, de los cuales los dos primeros son entendidos por el yo poético o locutorpersonaje como modelos, poseedores de un secreto místico o clave para la creación. Al observar la estructura narrativa del poema, se puede visualizar un proceso que parte de la descripción objetiva a la interpelación subjetiva: el yo poético describe a Chopin, alocutario figural del texto, como un sujeto prototípico que usa la soledad cual estrategia de empoderamiento a fin de revelar una verdad interior ("la Música de su alma”). Sobre él, destaca que su estado de aislamiento facilita la percepción de su propia voz, lejos del ruido y las reconvenciones sociales; y, luego, realiza una invocación a su genio, para aprender de él.

Dicho esto, por la disposición de los versos, podemos reconocer en el poema dos segmentos bien diferenciados. Los primeros catorce versos se orientan a plantear la identificación de las posibilidades creativas desencadenadas gracias a la soledad. Para ello, se despoja a esta condición de las connotaciones negativas con las que habitualmente se la relaciona: tristeza, apatía, desamor, muerte, y se la observa bajo un lente positivo, como fuente de poder, imaginación, inspiración y libertad creadora. El tropo que sirve para exponer esta nueva perspectiva es el paralelismo, el cual, en este caso, lúdicamente pone en tensión los campos figurativos de la repetición y la antítesis: en el poema se expone la situación vulnerable de un hipotético niño postergado por su entorno (primer, segundo y tercer verso); y luego el problema es trastocado en oportunidad (cuarto, quinto y sexto verso). En términos metafóricos, el sentimiento de aflicción, que en principio a-terra (metáfora orientacional la tristeza es abajo), pues recuerda la materialidad humana, es convertido en un estado de entusiasmo (alentador), que proyecta al personaje representado Chopin a una condición superior (la alegría es arriba): la creación. La inversión semántica lograda expone un empoderamiento que, espiritualmente, salvaguarda al alocutario de la incomprensión de su entorno: pudo objetivar lo impalpable (“escribió aquella música de su alma”) a pesar de ser 
un outsider ("bajo un sol que no era el suyo"). En este sentido, la nueva presentación de la figura del niño con la que se compara al artista Chopin es significativa: revela la necesidad de una reinterpretación de la infancia, una etapa de la vida que, antiguamente, era desatendida por la sociedad, relegada bajo la tutela de los instructores. Su visualización bajo un nuevo lente es necesario porque, en su pureza, posee el secreto de la composición artística, tal y como se expone en los cuatro últimos versos.

Claramente, una herencia romántica se insinúa en el estrato profundo del poema: se sugiere que la afirmación del yo subjetivo (la voz personal) es imprescindible para un encuentro satisfactorio con el otro. Sin embargo, es innegable la tendencia moderna de la representación del artista, cuya soledad no nutre un sentimiento de melancolía (sentimentalismo estéril); por el contrario, sostiene la fuente de una alegría creadora (impulsora del genio a estadios superiores). Por ello, consideramos que la apelación a la figura del niño se debe al reconocimiento de su capacidad para transformar lo ruin en algo bello. Su sensibilidad, su sentido afirmativo de la vida y su facultad para ver lo maravilloso cotidiano es revolucionaria, pues liberan al hombre de un pensamiento esclavizante. Esta cosmovisión se percibirá de modo más definido en el uso del poeta de los recursos formales.

\section{RASGOS FORMALES DE CORTE INFANTIL EN LOS MODOS DE PRODUCCIÓN ARTÍ́STICA DE LUIS HERNÁNDEZ}

Como ya se mencionó anteriormente, en los años 60 y 70, persistía una "crisis de experiencia" heredada de las guerras mundiales, la cual era avivada por la incertidumbre provocada por una serie de conflictos políticos nacionales e internacionales. A ello se sumaba el trance de una cultura cada vez más alienada, un espíritu embotado por la rutina de las ciudades modernas. En ese contexto, específicamente en el campo artístico, en palabras de Agamben (2007), la poesía moderna evidenciaría nuevamente su objetivo de "aferrar el Erlebnis” (la experiencia vivida), misión adoptada de la filosofía 
vitalista del siglo XIX ${ }^{14}$ y esbozada ya antes por los románticos. Algunos neovanguardistas, por ejemplo, explorarían estéticamente dicha carencia de experiencia transmisible hasta rescatar algo digno de ella. Procedieron a explorar los restos de la modernidad histórica y a construir a partir de ella. Además, impulsaron la reivindicación de la imaginación como fuente de nuevas experiencias; así como también reconocieron en la infancia "el último refugio de la experiencia”, por su alegre facultad para la aventura (35). Esto suministraría algunas bases para sobreponerse a la negatividad. En este contexto, cobra sentido la poesía de Luis Hernández, partícipe de esta aventura poética, la cual inició incluso desde Las constelaciones, poemario en el que ya se percibía la influencia específica del vitalismo de Nietzsche ${ }^{15}$.

Para Nietzsche (2007), la transformación en un superhombre implicaba "volverse un niño" en el sentido de volver a nacer bajo una condición superior, caracterizada por ser afirmativa y libre de toda domesticación. Así, en lugar de la configuración del infante bajo una perspectiva cristiana (puro e inocente por desconocimiento de la noción de pecado, y por la facilidad con que puede asimilar y confiar en Dios-padre), el filósofo ofreció una nueva representación: el niño como símbolo del vitalismo, el inconformismo, el cuestionamiento, la libertad, el desprendimiento despreocupado,

14 De acuerdo con Agamben (2007), realizaron este intento de aferrar el Erlebnis, por ejemplo, Charles Baudelaire (en su representación de Constantin Guys como coleccionista de experiencias urbanas), Marcel Proust (por su acumulación maravillosa tanto de sensaciones como de objetos) y Rilke (seducido por la expresión del tiempo en el cual las personas acumulaban lo humano).

${ }^{15}$ En el epígrafe que apertura Las constelaciones, figura un fragmento de Así habló Zaratustra: "Bendíceme, pues, tú, ojo tranquilo / Que sin envidia puedes ver / Una dicha demasiado grande”. Al igual que para Luis Hernández, la soledad es, en dicha obra del filósofo, un estado que posibilita una condición superior. En esta situación, el ser iluminado no puede contener su propia luz (el fuego) y debe irradiarla entre los demás a través de su voz (su canción, su creación). Por ello, Zaratustra invoca al ente solar, para que, una vez que esté entre los hombres no-iluminados, no se vea afectado por ellos, como el sol que puede hundirse en el ocaso y volver a surgir incólume. La metáfora del sol poniente también se puede visualizar constantemente en la poesía de Hernández (Im abendrot), pero su estudio, como parte de una relación intertextual entre el poeta y Nietzsche, requeriría un espacio aparte para su desarrollo. 
la audacia y la creatividad. Únicamente el niño posee la facultad natural de resistir la domesticación, así como la opresión de la gravedad y el compromiso en un mundo organizado que para él aún es inconcreto; por ello, puede generar nuevos valores. En este sentido, cabe aclarar que la inocencia y la pureza a las cuales se refiere Nietzsche, y que luego adoptaría Luis Hernández, principalmente para sus experimentaciones formales, se hallan más allá de los conceptos del bien y el mal; más bien, aluden a la libertad para crear. Así, el filósofo declaraba lo siguiente: “¿Dónde hay inocencia? Allí donde hay voluntad de crear. Y el que quiere crear más allá de sí mismo, ese es quien tiene para mí la voluntad más pura" (111). El impulso a la creación sin mediación, sin orden impuesto ni razonamiento limitante es característica de la voluntad de crear del ser inocente. En consecuencia, es necesario "volverse niños" voluntariamente para fortalecer la facultad de creación y liberarse de las ataduras que la frenan ${ }^{16}$. Desde este punto de vista, se atisba la subversión de la tradición inspirada en la esencia lúdica del infante. Así, Luis Hernández, como poeta moderno, reinterpretó y recuperó su infancia a voluntad, exploró nuevos caminos y, una vez transformado, como Zaratustra, buscó a los “otros” para irradiar su conocimiento y trascender su soledad, regalando sus cuadernos poéticos.

En virtud de lo expuesto, en la poesía de Hernández, se pueden identificar una serie de rasgos propios del ámbito infantil, por los que podemos comprenderlo como un "artista-niño" en el sentido planteado por Baudelaire (por "recuperar su infancia a voluntad"), Nietzsche y los vanguardistas. Como primer aspecto, destaca la alegría infantil en la base de sus procedimientos formales de creación. En su obra, el espíritu alegre del niño se erige contra la muerte,

\footnotetext{
16 En este sentido, Nietzsche (2007) describe las tres metamorfosis que el hombre debe atravesar para consolidar una condición superior: el camello (la bestia reverente y servil), el león (la bestia con voluntad de poder) y el niño (la instancia liberada potencialmente creadora): "Inocencia es el niño y olvido, un nuevo inicio, un juego, una rueda que gira por sí misma, un primer movimiento, un sagrado decir "sî”. Sí, hermanos míos, para el juego de la creación es necesario un sagrado decir sí; el espíritu quiere ahora su propia voluntad, quien se ha retirado del mundo conquista ahora su mundo" (32).
} 
el espíritu embotado y el sentimiento de culpa religioso ${ }^{17}$, lo que le posibilita la realización de una obra artística colmada de salud, orientada a desmitificar el mundo como parte de su afirmación de la negatividad moderna. El poeta, pues, modifica su conciencia existente por medio del juego, como un infante que, protegido por su inocencia, posee la facultad de sobrevivir a lo trágico por medio de diversos mecanismos: la risa per se (el yo poético explota su eficacia por medio del humor blanco, la parodia y el disparate puro), el disfraz (mediante el uso de identidades múltiples), el juego lingüístico (mediante las transgresiones semánticas y el chiste), el dibujo y el garabato (por medio de la creación de motivos, como flores, elefantes, niños, playas, etc., con plumones). Así, por ejemplo, se pueden encontrar versos cargados de humor que se burlan de la instauración de jerarquías y la ambición de poder: "Estimado General / Nosotros, el General / El General / El General / y el General / Invitamos a Ud / En la casa del General / Para tratar / De ver / Cuál General / Es más General / Quizás lo sea Ud / U otro General / firma / General / (en representación del General, el General y el General)" (La novela de la isla, 155). En este caso, la repetición del rango militar parodia la obsesión compulsiva por lograr el más alto grado de dominio. Más claramente, simula un remedo infantil a través de la geminación, que hace escarnio de las autoridades representadas de forma grotesca y absurda.

Asimismo, es relevante, la complacencia del poeta por el uso del disfraz, práctica empleada por los niños y el hombre primitivo para renovarse y empoderarse. Un espacio en el que se evidencia ello es Una impecable soledad, "poema en prosa" experimental

\footnotetext{
17 El tema de la culpa en la poesía de Hernández parte de la conciencia que adopta el yo poético de su propia existencia, de "arrojado en el mundo", en el cual es responsable como todo sujeto del devenir de la historia. Bajo este prisma, pueden leerse poemas como, por ejemplo, "Abel” (en el que se lamenta el extravío del hermano) y "He visto" (donde se aborda la responsabilidad humana ante el holocausto judío). Al respecto, resultaría interesante abordar el motivo religioso en la obra como objeto de una futura investigación. Por el momento, baste señalar que, si bien él se presenta en el nivel temático de los versos hernandianos, la superación de la carga moral se plantea mediante el humor, el juego retórico y otros recursos lúdico-formales que la desdramatizan.
} 
(Chueca 2010: 262) que presenta ante el lector a un personaje configurado como un artista-niño (con algunas similitudes con respecto a la representación de Constantin Guys de El pintor de la vida moderna), disfrazado continuamente en sus vagabundeos urbanos y recitales de piano. Este personaje es despojado de una identidad fija como la que posee cualquier persona (del latín persona y el griego $\pi \rho o ́ \sigma \omega \pi \mathrm{ov}$, máscara); es decir, es despersonalizado y expuesto con una condición plural debido a su constante renombramiento. En la base de esta renominación continua se halla la metáfora ontológica el nombre es una máscara, que es común de ser hallada en enunciados como "Si no supieras su nombre, sabrías que es un hombre amable", "Usó un nombre rimbombante solo con el fin de impresionar”. A partir de esta, con una intención crítica, además de juguetona, el poeta irónicamente trató de demostrar que todos los hombres son iguales (igualmente humanos) por encima de las diferencias, las convenciones y las caretas. En virtud de ello, generó una serie de identificaciones: Shelley Álvarez es, ciertamente, igual que John Keats Álvarez, Gran Jefe Un Lado del Cielo, el Príncipe One-side-of-the-sky, Byron, Gran Jefe un Keats del Cielo, Aleksandr Álvarez, Gran Jefe Un Lado de Shelley, Keats Álvarez, Lawn Tennyson Álvarez, Gran Tipo Byron Álvarez, Alfred Álvarez, etc. ${ }^{18}$, renovado de forma persistente como una manera de rehuir al control social, pues se tiene poder sobre lo que se nombra, y lo que el poeta desea es una "liberación” de su concepción como objeto: el ser bumano no es mueble fue la metáfora ontológica que empleó para manifestar "la conclusión a la que llegara Shelley luego de ejecutar de memoria y de pie los Estudios Trascendentales de Ferenc Liszt, llamado Franz en algunas regiones centroeuropeas” (345).

\footnotetext{
18 Estos son nombres creados a partir de autores y personajes de diferentes lecturas de Hernández: John Keats (el vate de la imaginación), Jefe Seattle (líder de una comunidad amerindia continuamente referenciado por el poeta), George Gordon Byron (poeta romántico), Percy Bysshe Shelley (que escribió Prometeo liberado), Alfred Tennyson (poeta posromántico), Aleksandr Pushkin (romántico también) y el Principito (protagonista de una obra narrativa de Antoine de Saint-Exupéry, quien, desde la perspectiva de la inocencia infantil, evidenció ciertas claves de la condición humana).
} 
De este modo, el poeta libera la percepción de la identidad gracias a la imaginación, tal y como un niño lo haría, indiferente a convenciones, asemejándose con otros por su sensibilidad, su comprensión de la vida o su disidencia. En el mismo sentido, "Shelley Álvarez" es identificado con todos los niños y artistas del mundo (esos "seres alados" de "corazón transparente”), “incomprendidos”, "torturados", “instruidos”, tratados como "locos”, pero satisfechos con su arte, como el torturado Arthur Rimbaud, el incomprendido Luchito Hernández, el solitario Chopin, el prodigioso Mozart y el Principito: “[Shelley Álvarez] De niño oyó de alguien decir: pobre, tan solitario. Pero no comprendió por qué pobre” (358), pues la soledad para él, al igual que en el caso de "Chopin”, es una circunstancia que facilita el reconocimiento de saberse "misterioso" y capaz de lograr su autorrealización. No obstante, es necesario precisar aquí nuevamente que la identificación de Shelley Álvarez con un “artista-niño" se realiza en el sentido nietzscheano de que se recupera para él una condición libre de toda domesticación para luego poder crear. En el conjunto poético de Una impecable soledad, hay dos momentos claros en la definición del personaje: primero como un ser primitivo-niño (ya evidenciado en líneas anteriores); y, después de una metamorfosis, como un ser creador: "Keats Álvarez retornó a su casa, regando de arena reluciente todas las habitaciones, pues fuera del piano y la Melancolía era un Austrolophitecus, un Mowli” (346). Solo la música le puede brindar la posibilidad de superar esa instancia primitiva y alcanzar el ideal estético, el cual lo hace plenamente humano, libre de toda máscara.

En cuanto al empleo del juego retórico, destacan los versos en los que se plantea la distorsión léxico-semántica y la "ambivalencia” como formas de socavar la seriedad intelectual: "Es una especie / de Robinson / pero cruzado" (202); "Ortega y / Gasset / y cassette” (203); "Los laureles / se emplean / en los poetas / y los tallarines" (203); "El origen de Darwin según el mono" (212); “Creo en el plagio / y con el plagio creo" (303). Se trata de un procedimiento formal intencionalmente despreocupado con el cual el poeta crea un espacio de horizontalidad y familiarización entre los lectores y los 
referentes de la cultura, a quienes incluso cita, copia y adhiere a su poesía con un fin renovador. Esta alegre tendencia destructiva del aura del ejercicio poético posee un rasgo particularmente infantil, ya que el poeta, como un niño, se desentiende de que todo lo que lo rodea sea un espacio ya organizado: él mismo establece su propio orden y presenta la "destrucción” como una condición necesaria para una nueva construcción. Debido a esto, frente al contexto de crisis, se puede percibir en la poesía de Hernández la creación de un tiempo de felicidad, acorde con el tiempo eterno del aión contrapuesto al tiempo diacrónico y progresivo (chronos) ${ }^{19}$. Gracias al juego, como principal herramienta de transgresión, estableció así un terreno de "liberación transitoria", en palabras de Bajtín (1988), de degradaciones, profanaciones y derrocamientos bufonescos, entre los cuales, incluso, el propio autor se vería afectado. Ejecutó, de esta forma, una experiencia poética subversiva que sus coetáneos seguirían, deseosos de transgresiones.

Como segundo aspecto, es preciso mencionar la espontaneidad infantil reconocida por Luis Hernández como un recurso auténtico de creación. El poeta (autorrepresentado como "Luchito" o "Luisito", el outsider "Billy The Kid”), reivindicando su autonomía, no se percibía como un siervo de la naturaleza ni de los cánones oficiales ni del sistema, y por eso recusó los patrones del Arte. Por ejemplo, se independizó de los valores formales sofisticados basado en criterios de armonía y perfección, puesto que no comprendía la creación en un sentido progresivo. En consecuencia, no corregía sus poemas y dejaba que brotaran (Zisman 1975a: 11), "Porque la literatura / No es artificio / Sino Dignidad" (El jardín de los cherris, 131). En lugar de ello, expresaba las imágenes de lo “maravilloso

19 De acuerdo con Agamben (2007), resulta sugerente pensar que, ya antiguamente, Heráclito proponía comprender al tiempo-aión cual “niño que juega a los dados”, un tiempo eterno. Esto motiva a resaltar la particular "fuerza vital”, característica del infante que se resiste al tiempo del reloj, regulador y administrable (chrónos). Asumiendo una similar condición, el artista moderno intentó un acto revolucionario: no solo "cambiar el mundo", como había sido la consigna saintsimoniana, sino principalmente "cambiar el tiempo” (131) y la agobiante visión que se tenía sobre él. Para ello, la perspectiva lúdica sería fundamental. 
cotidiano" en forma natural, con la transparencia de un infante que ignora trucos retóricos de representación. De esta forma, ajeno a toda preocupación moral y estética, podía lograr un nivel más elevado de autenticidad. Esta es una cualidad que Benjamin (1989a) admiraba de los infantes: "Lo que se obtiene de los niños por la fuerza, como "rendimiento" acabado, nunca puede compararse, en cuanto a autenticidad, con la improvisación” (105).

Del mismo modo, Hernández (así como los vanguardistas de inicios del siglo XX) optó por despreocuparse de agradar al público y relegar tanto el oficio de "artista" como la tradicional idea de su "virtuosismo". Se trata de una inclinación hacia la autenticidad heredada del romanticismo. De acuerdo con Gombrich (2011): "Mientras que, en el mundo antiguo, lo mismo que en el siglo XVIII, los artistas consideraban que su tarea consistía en describir las pasiones con objetividad y precisión, el artista romántico se proponía expresar y comunicar sus propias emociones con absoluta sinceridad" (207). Ello podía efectuarse asumiendo la capacidad de asombro y la espontaneidad de un niño. Así, el poeta escribiría "UN NIÑO mira el Verano / Como lo hacen los niños / Con los ojos abiertos mira abuelo / Cómo el muy-muy que habita / En su choza de arena / Se asemeja al Verano y su muda / Canción también es bella" (Ars poética, 72; énfasis nuestro). Según Rancière (2009), en este régimen de expresividad característico de una poética generalizada que se impuso ante la poética restringida de antaño, se afianza una analogía entre lenguaje, sociedad y espíritu. Bajo este concepto, la poesía moderna expresa, como palabra viva, el mundo, ya que ella misma "es un fragmento del poema del mundo" (54). "Expresión” sería una palabra clave en la poesía de Hernández, pues más allá de toda norma poética reconoció en el propio lenguaje su capacidad para manifestar la poeticidad del mundo (de las cosas mudas que lo conforman: la piedra, el aserrín, el cielo, el sol...) en cuanto posee en su estructura la experiencia del mundo. En este sentido, el artificio poético como medio expresivo es una traba que el poeta descarta y erige la práctica escrituraria de una poesía sencilla: “(...) O mejor aún, creo escribir Sin segundas intenciones (...) / Y creo 
que la Poesía / Es entregar al Universo / El propio corazón (...)” (Ars poética, 296-297).

Un tercer aspecto formal que caracteriza al artista-niño Hernández en su poesía es su visión material del mundo: todo es materia en potencia para consumir y experimentar. Cual infante en su etapa sensoriomotora, extasiado por su imaginación, antes que tentar la simbolización, agarra, fragmenta, juega. Por ejemplo, fragmenta los textos y las palabras como si buscase su "alma interior", un nuevo sentido además del ordinario o canónico. Asimismo, mezcla democráticamente los materiales más heterogéneos (papel, cartón, plumones, pintura, lenguas, culturas y contextos distintos, etc.) sin reconocer su origen, estado o historia y les otorga un sentido propio. Así, experimentando su poder, desafía el sentido de todo lo que existe en acto y diversifica las posibilidades. En palabras de Agamben (2007), "vive su propia posibilidad" (29). Esta visión material del artista-niño se nutre de su espíritu de coleccionista. Ya en Le Peintre de la vie moderne, Baudelaire (2005) había comentado su activo interés por las cosas, aun por lo más marginal: desde un principio, el niño es ya un cazador y todo lo que halla en su entorno es el comienzo de una colección (Benjamin 1989a: 98). Del mismo modo, Hernández comprendía las palabras en un sentido material. Sean propias de la cultura popular (fragmentos de canciones, cómics, jergas) o de la tradición científica (citas, fórmulas matemáticas, códigos de la medicina y la biología) o de la literatura (poesía, novela, teatro, ensayo, crónica social) o del ámbito musical (notas musicales, biografías de compositores), sean de un idioma o de otro, las coleccionaba, las "curaba" de su hechizo (despojándolas de su "aura"), las mezclaba y generaba nuevos cuerpos textuales.

Como consecuencia de dicho procedimiento formal, sus escritos problematizan el continuum de la historia literaria y la sistematización de la creatividad literaria por medio de categorías de género. De esta forma, es difícil afirmar, por ejemplo, que Una impecable soledad sea una obra narrativa, cuando en ella confluyen la prosa y el verso, el léxico musical y la técnica cinematográfica. Es en este sentido que quizá el poeta afirmaba en $E l$ sol lila: "Cultivo un género 
/ Que fue descrito / Como un neoclasicismo / Hirsuto” (192), pues creaba textos "dispersos", “despeinados”, contrarios a los preceptos literarios clásicos. Evidenció, así, una orientación plástica y democrática sobre el arte, pues al jugar con diferentes elementos disolvía distancias y tensiones. Su visión descentrada, embriagada por la curiosidad y la posibilidad de acoger el mundo en su totalidad, sin reconocer los límites ${ }^{20}$, le posibilitó tentar una nueva armonía, acaso solo imaginable en el terreno de juego del lenguaje, su nuevo jardín ideal, en el que podía disfrutar de “otra” temporalidad.

Como cuarto aspecto, cabe destacar que, con la desarticulación física de su obra, Luis Hernández expresó un rotundo desinterés de los principios de utilidad, funcionalidad y reproductibilidad propios de la subjetividad burguesa dominada por una conciencia mercantil y progresista. Sobre la base de esta disidencia, pudo transgredir formalmente la producción y el consumo de un libro convencional. Transformó el terreno de la poesía en un espacio donde todo podía confluir gracias al canto y podía hallarse exento de la demanda de ser útil, como en el reino del juego. Como un niño que desarticula el juguete burgués y el libro dispuestos para su disciplina o formación, él, dominado por una tendencia destructiva infantil, desorganizó la estructura de su obra, donde halló espacios en blanco, garabateó, dibujó; y, finalmente, la presentó no como una "propiedad funcional", sino como un objeto en devenir para el placer y la re-creación continua ${ }^{21}$. Como un infante, se manifestaba

\footnotetext{
20 Debido a esta práctica creativa desinhibida, en otro espacio la vinculamos con una pulsión orgiástica (León 2019). Para ello, partimos de los razonamientos de Eduard Fuchs, citado por Benjamin (1989b), en torno al fundamento erótico de la iniciativa creativa del sujeto artístico. De acuerdo con Fuchs, “[...] el placer orgiástico [...] pertenece a las tendencias más valiosas de la cultura... debemos tener claro que la orgía... forma parte de lo que nos distingue del animal. Este, al contrario que el hombre, no conoce la orgía... El animal se retira de la pitanza más sabrosa y de la fuente más cristalina, cuando ha aplacado su hambre y su sed, y su urgencia sexual se limita generalmente a breves y determinados periodos del año. Otra cosa muy distinta ocurre al hombre, sobre todo al hombre creador. Este ni conoce el concepto de suficiente" (125; énfasis nuestro). El artista que se dice "libre" es indiferente a todo límite, así como también lo son en principio los infantes.

${ }_{21}$ Véase Barthes ([1957] 1999), donde se explica cómo el infante interactúa con el juguete burgués destruyéndolo, puesto que, ante él, no se autopercibe como un "usuario".
} 
indiferente a la aprobación del "sentido", ya que, como afirma Benjamin (1989a), "Lo que persigue toda realización infantil no es la "perpetuidad" de los productos, sino el "momento" del gesto" (105). En consecuencia, nos situó ante la comprensión del libro como un juguete textual lingüístico, fragmentado, inacabable y sin proyección pecuniaria ${ }^{22}$. Es más, con su dispersión entre diferentes receptores-amigos, su poesía complejizó su reproductibilidad técnica y planteó la necesidad de una revisión de la tradición del libro, principalmente de aquellos ejemplares que subvertían los modos de producción convencionales y, más aún, el status del arte y su consumo. Pudo, así, transgredir la lógica de lo que Bürger ([1974] 2000: 62) denominó “Institución Arte”, aparato organizado que administra los procesos de producción, difusión y consumo simbólicos del arte, así como se establecen ciertos conceptos dominantes, los cuales influyen decisivamente en la recepción de las obras. Finalmente, puede afirmarse que nos legó un obra auténtica y única, acorde con los anhelos de los primigenios artistas modernos.

El niño es, esencialmente, un creador y es indiferente al valor de cualquier objeto que incluso represente su ámbito social originario (clase social, religión, etc.). Por tal razón, es un individuo democrático que prefiere los juegos de construcción, ya que absorto con ellos, "el niño no crea objetos significativos, le importa poco que tengan un nombre adulto; no ejerce un uso, sino una demiurgia: crea formas que andan, que dan vueltas, crea una vida, no una propiedad" (33).

22 Creemos que Luis Hernández hace de la reescritura una auténtica fiesta expresiva (una de sus armas contra el dolor). A esta transgresora forma de escribir la comprendimos, en otro espacio, como una tentativa de "poética órgica” (León 2019), en la línea de los vates de mediados del siglo XX, que rechazaban el intelectualismo (Mallarmé, Guide, Giradoux, Proust, Alain, Valéry, Suarès, los surrealistas...) y parodiaban las obras organizadas. La poesía de Hernández hace eco, principalmente, de Mallarmé, quien fue uno de los más claros en problematizar la concepción del "libro", su ambicionada organicidad y las fronteras del silencio, pero se diferenció por buscar aprehender la belleza por una vía alógica: la erótica. Él escribió “Qué laberinto / y qué amor / es la poesía” (Hernández 1983: 162). Influenciado por la visión desinhibida del movimiento hippie y el espíritu dionisíaco nietzscheano, evidenció un deseo irregulado de arte, contrario a la noción disciplinada de la actividad creadora. 


\section{Conclusión}

La obra de Luis Hernández, principalmente en el ámbito formal, posee rasgos infantiles porque el "niño" en su poética lúdica es una clave de creación en relación con el lenguaje, una metáfora de la audacia experimental, la despreocupación, la libertad creadora y la videncia, que lo facultó para redescubrir lo cotidiano, sorprenderse y escudriñar en lo superficial. "Mirar con ojos nuevos" fue una intención clara que tuvo, es decir, nacer como poeta bajo una nueva condición, libre de corsés formales y demandas sociales. Esta actitud de corte vanguardista de resaltar la crisis de los valores literarios instituidos se manifiesta metafóricamente como un efecto de su pérdida de fe en el campo literario, uno en el que dejó de creer. Por ello, el poeta tentó una recuperación consciente del paraíso perdido en un sentido estético para armarse con una de las más poderosas facultades humanas en el terreno de la creación: la imaginación; y asumió la infancia en el aquí y ahora, como una condición constantemente presente en su proceso creativo. Disponiendo de esta, expuso la poesía como un espacio ideal para el establecimiento de una nueva pureza, una de naturaleza estética, que atisbó en los artistas que lo fascinaban y a los que representó en sus poemas (Rimbaud, Chopin, Mozart, Beethoven, etc.).

La poesía, para él, fue un campo de juego donde le era posible establecer el imperio de la alegría, el amor y la libertad. De esta manera, se visibiliza una metáfora ontológica presente de forma transversal en toda su obra: la poesía es un jardín, uno en el que el artista-niño puede jugar libremente. El poeta es quien domestica lo que halla en su entorno y consolida una belleza propia: reorganiza la naturaleza potenciado por su imaginación. La expresión democrática es posible en su territorio, así como el juego, el ensayo, el collage, la vida misma palpitando en cada hoja, un nuevo orden en el que se descarta la perspectiva angustiosa que se tiene en torno del tiempo; y la destrucción es comprendida como parte de la vida, con un carácter renovador, tal y como sucede en el reino del niño inmerso en el tiempo de la fiesta. Bajo este lente, afirmaba: 
“MIRABA siempre / En el jardín / No fuese a ser / Aquel / El jardín / Que perdiera / Y sí lo fue. / Pero hallé otro jardín / Desde el cual / Cantar. Canto / Y ese es mi / Motivo personal / Para cantar: La Canción” (El sol lila, 179). Gracias a la alegría de esta pasión revolucionaria de cuño vanguardista, dispuesto a poner todos los valores consagrados en crisis, Luis Hernández erigió en sus manos el fuego-juego infantil (como Zaratrustra) que refrescaría la poesía vigente en los años 60 y 70.

\section{REFERENCIAS BIBLIOGRÁFICAS}

Agamben, Giorgio

2007 Infancia e historia. Destrucción de la experiencia y origen de la bistoria. Traducción de Silvio Mattoni. Buenos Aires: Adriana Hidalgo editora.

Arduini, Stefano

2000 Prolegómenos a una teoría general de las figuras. Murcia: Universidad, Servicio de Publicaciones.

BAJTín, Mijail

1988 La cultura popular en la Edad Media y en el Renacimiento. Traducción de Julio Forcat y César Conroy. Madrid: Alianza Editorial.

BALdoni, Micaela

2012 "La aparente paradoja de la sociología de un genio. Mozart... un análisis paradigmático de la perspectiva de Norbert Elias". Nómadas. 33, 1, enero-junio. Consultado: 13 de julio de 2020. $<$ http://www.redalyc.org/articulo.oa?id=18123129021> .

BARroso, Julia

2005 Tema, iconografía y forma en las vanguardias artísticas. Asturias: Castrillón.

BARTHEs, Roland

[1957]1999 “Juguetes”. En Mitologías. Traducción de Héctor Schmucler. 12. ${ }^{a}$ ed. Madrid: Siglo veintiuno editores, 33-34.

Baudelaire, Charles

2005 El pintor de la vida moderna. Traducción, presentación y notas de Julio Azcoaga. Córdoba: Alción. 
BENJAMIN, Walter

1989a Escritos. La literatura infantil, los niños y los jóvenes. Consultado: 15 de junio de 2019. < bit.ly/39wnrfx $>$.

Benjamin, Walter

1989b “El carácter destructivo"; "Experiencia y pobreza”. En Discursos interrumpidos I. Filosofía del arte y la historia. Prólogo, traducción y notas de Jesús Aguirre. Buenos Aires: Taurus, 157-163 y 165-173, respectivamente.

BÜRgER, Peter

[1974] 2000 Teoría de la vanguardia. Traducción de Jorge García. 3. ed. Barcelona: Ediciones Península.

Calinescu, Matei

2003 "La idea de vanguardia. Cinco caras de la modernidad". En Cinco caras de la modernidad. Modernismo, vanguardia, decadencia, kitsch, posmodernismo. Traducción de Francisco Rodríguez Martín. Madrid: Alianza Editorial, 103-152.

Carrillo, Francisco (comp.)

1965 Antología de la poesía peruana joven. Lima: Ediciones de la Rama Florida.

Cevallos, Leonidas

1967 Los nuevos. Miraflores: Editorial Universitaria.

Chueca, Luis Fernando

2006 "La muerte la basura / El langoy y la locura". En En la comarca oscura. Lima en la poesía peruana 1950-2000. Eds., Luis Chueca, José Güich, y Carlos López Degregori. Lima: Fondo Editorial de la Universidad de Lima, 69-92.

Chueca, Luis Fernando

2010 "Desdoblamientos y exploración poética frente al dolor en Una impecable soledad de Luis Hernández". En Umbrales y márgenes. El poema en prosa en el Perú contemporáneo. Eds., Luis Chueca, José Güich, Carlos López y Alejandro Susti. Lima: Fondo Editorial de la Universidad de Lima, 255-287.

De Micheli, Mario

2000 Las vanguardias artísticas del siglo XX. Traducción de Ángel Sánchez Gijón. Madrid: Alianza Editorial. 
De Torre, Guillermo

2001 Historia de las literaturas de vanguardia. Madrid: Visor Libros.

EscoBAR, Alberto

1965 Antología de la poesía peruana. Prólogo, selección y notas de Alberto Escobar. Lima: Nuevo Mundo.

EsCOBAR, Alberto

1973 Antología de la poesía peruana 1960-1973. Tomo II. Lima: PEISA, Biblioteca Peruana.

Fernández Cozman, Camilo

[2001] 2009 Rodolfo Hinostroza y la poesía de los años sesenta. 2. ${ }^{a}$ ed. Lima: Fondo Editorial de la Universidad de Ciencias y Humanidades.

García-Bedoya, Carlos

2012 "Trayectoria del vanguardismo peruano. (Esquema de trabajo)". En Indagaciones heterogéneas. Estudios sobre literatura y cultura. Lima: Pakarina, 241-252.

Gilman, Claudia

2003 Entre la pluma y el fusil. Debates y dilemas del escritor revoIncionario en América Latina. Buenos Aires: Siglo Veintiuno editores.

Gombrich, Ernst

2011 La preferencia por lo primitivo. Episodios de la historia del gusto y el arte de Occidente. Traducción de Juan Manuel Ibeas. Londres: Phaidon.

GonZÁlez Vigil, Ricardo

1978 "La canción de Hernández". El Dominical, suplemento de El Comercio, 77-78, 20. 2 de julio. Consultado: 3 de marzo de 2020.

Guerrero, Claudio

2008 "Infancia, romanticismo y modernidad". Revista de Humanidades. 17-18, junio-diciembre, 171-186. Consultado: 10 de octubre de 2019. <https://www.redalyc.org/ $\mathrm{pdf} / 3212 / 321227236010 . \mathrm{pdf}>$. 
HABERMAS, Jürgen

2004 "Modernidad: un proyecto incompleto". En El debate modernidad-posmodernidad. Comp., Nicolás Casullo. Buenos Aires: Retórica, 53-63.

HERNÁNDEZ, Luis

1965 Las constelaciones. Trujillo: Cuadernos Trimestrales de Poesía, 36, diciembre

HERNÁNDEZ, Luis

1978 Vox horrísona. Tomo 1. Prólogo, recopilación y notas de Nicolás Yerovi. Lima: Ames.

HERNÁNDEZ, Luis

1983 Obra poética completa. 2. ${ }^{a}$ ed. Ampliada con nuevos textos recogidos por Nicolás Yerovi; prólogo de Javier Sologuren; edición y notas de Ernesto Mora. Lima: Punto y Trama.

HERNÁNDEZ, Luis

1995 Trazos de los dedos silenciosos. Antología poética. Selección, prólogo y notas de Edgar O’Hara. Lima: Petróleos del Perú, Jaime Campodónico editor.

HERNÁNDEZ, Luis

1997 Una impecable soledad. Edición, estudio y notas de Edgar O’Hara. Lima: Ediciones de los Lunes.

HERNÁNDEZ, Luis

2003 Cuadernos de Luis Hernández. Lima: Colecciones Especiales de la Biblioteca Central de la Pontificia Universidad Católica del Perú; Oficina de Comunicación Digital. Consultado: 19 de setiembre de 2020. <https://biblioteca.pucp.edu.pe/luishernandez/>.

HERNÁNDEZ, Luis

2007 La soñada coherencia. Prólogo, notas y selección de Edgar O’Hara; dosier fotográfico del archivo de Herman Schwarz. Lima: Mesa Redonda.

Higgins, James

1993

"Una generación contestataria: los poetas del 60. Nuevos esquemas y un nuevo espíritu”. En Hitos de la poesía peruana. Siglo XX. Lima: Editorial Milla Batres, 151-155. 
HuizingA, Johan

2007 Homo ludens. Traducción de Eugenio Imaz. Madrid: Alianza editorial.

LAKOFF, George y Mark JoHnson

1995 Metáforas de la vida cotidiana. 2. ${ }^{\text {a }}$ ed. Introducción de José Antonio Millán y Susana Narotzky. Madrid: Cátedra.

LEÓN, Liz Fiorella

2019 "Crisis de la "obra orgánica" u "obra organizada" en Vox borrísona, de Luis Hernández". Metáfora. Revista de literatura y análisis del discurso. 3, 1-21. Consultado: 12 de agosto de 2020. <http://www.metaforarevista.com/articulos03_leon. html>.

López Degregori, Carlos y Edgar O’Hara

1998 Generación poética peruana del 60. Estudio y muestra. Lima: Universidad de Lima; Fondo de Desarrollo Editorial.

Mendoza-Canales, Ricardo

2009 "Parodia y desmitificación en la poesía de Luis Hernández". Lexis, XXXIII, 2, 255-286. Consultado: 14 de diciembre de 2018. <http://revistas.pucp.edu.pe/index.php/lexis/article/ view/1737>.

Mendoza-Canales, Ricardo

2013 “Topografías del devenir: la poesía de Luis Hernández”. Mitologías Hoy. Revista de pensamiento, crítica y estudios literarios latinoamericanos. 15, 199-216. Consultado: 17 de junio de 2020. <https://www.raco.cat/index.php/mitologias/article/ view/v15-mendoza/418720>.

Nietzsche, Friedrich

2007 Así habló Zaratustra. Traducción de Sergio Albano. Buenos Aires: Gráfico.

O'Hara, Edgar

1995a “Territorios de la palabra móvil”. En Trazos de los dedos silenciosos. Antología poética. Ed., Edgar O’Hara. Lima: Jaime Campodónico-Petroperú, XI-XXXIII.

O'Hara, Edgar

1995b “Los 30 años de Las constelaciones”. Debate. XVII, 84, Lima, septiembre-octubre, 55-57. 
O'HARA, Edgar

1997 “Prefacio". En Una impecable soledad. Ed., Edgar O’Hara. Lima: Ediciones de los Lunes, IX-XXIV.

O'HARA, Edgar

2007 “Treinta años de misterios y de poesía intacta: (Ele Hache, 1977-2007)”. Lienzo. 28, 9-41.

Orrillo, Winston

1968 "Poesía peruana actual: dos generaciones". Cuadernos Hispa-

Ortega, Julio noamericanos., 228, diciembre, 620-662.

1971 Imagen de la literatura peruana actual, 1968. Tomo III. Lima: Editorial Universitaria.

Ortega, Julio

1988 “Un modelo para armar. Poesía peruana contemporánea”. La República, Sección Artes E Letras, 30-32. 26 de junio. Consultado: 3 de marzo de 2020 .

Paz, Octavio

[1974] 1993 Los hijos del limo. Del romanticismo a la vanguardia. Barcelona: Editorial Seix Barral.

Rimbaud, Arthur

[1873] 2005 Una temporada en el infierno. Edición bilingüe de Javier del Prado. Madrid: Cátedra.

Rodríguez, Diana

2011 El juego del plagio en la poesía de Luis Hernández. Tesis para obtener el título de Licenciada en Estudios Latinoamericanos. México, D. F.: Universidad Nacional Autónoma de México.

ROMERo, Rafael

2008 La armonía de H. Vida y poesía de Luis Hernández Camarero. Lima: Jaime Campodónico editor

Rowe, William

1974 “Poesía peruana: los últimos diez años”. Variedades. Revista Semanal Ilustrada. 1261, La Crónica, Lima, tercer domingo de agosto, 18-19.

SCHILlER, Friedrich

[1795] 2016 Cartas sobre la educación estética del hombre. Traducción de Martín Zubiria. Mendoza: Universidad Nacional de Cuyo, 
Facultad de Filosofía y Letras. <http://bdigital.uncu.edu.ar/ objetos_digitales/7709/schiller-con-tapas.pdf $>$.

Sologuren, Javier

1963 Poesía. Prólogo de Luis Alberto Ratto. Lima. Ediciones del Sol.

SOlOGUREN, Javier

2005 Gravitaciones E Tangencias. Lima: PUCP.

Tamayo Vargas, Augusto

1970 Nueva poesía peruana (antología). Barcelona: Ediciones Saturno.

Tola de Habich, Fernando

1969 “Poesía joven del Perú”. Boletín. México, 4, junio, 27-43.

Tzara, Tristan

2009 "Manifiesto del señor antipirina”. En Escritos de arte de vanguardia 1900/1945. Eds., Ángel González, Francisco Calvo y Simón Marchán. Madrid: Ediciones Akal, 190-191.

Verástegui, Enrique

1975 "Breve informe (alegórico) de los años 60/70: una poética". Variedades, Revista Semanal Ilustrada de La Crónica. 1308, Lima, segundo domingo de julio, 9-10.

Vich, Víctor

2013 Voces más allá de lo simbólico. Ensayos sobre poesía peruana. México: Fondo de Cultura Económica.

Yerovi Díaz, Leonidas

1976 "Hacia una edición crítica de «Vox horrísona». (Poesía de Luis Hernández 1961-1976)". Tesis para optar por el grado de doctor en Lengua y Literatura. Lima: Pontificia Universidad Católica del Perú.

Zapata, Miguel Ángel y José Antonio MazzotTi

1995 El bosque de los huesos. Antología de la nueva poesía peruana 1963-1993. México: Editorial El Tucán de Virginia.

Zisman, Alex

1975 Luis Hernández: el arte de la poesía. Correo, 7 de junio, 11. 